\title{
Surgical Procedure Stopped
}

National Cancer Institute

\section{Source}

National Cancer Institute. Surgical Procedure Stopped. NCI Thesaurus. Code C50421.

Termination of a surgical intervention. 